\title{
Strengthening Collaborative Governance in Efforts to Reduce The Mortality Rate of Mother and Baby
}

\author{
Farida Nurani
}

Public Administration, FIA UB, Indonesia (email: farida_fia@ub.ac.id)

\begin{abstract}
This research aims to learn the role of each government agency and community involved in the policy program for reducing maternal and infant mortality rate in Jember district. Then hope to come up with recommendations for strengthening the role of stakeholders in an effort to realize good governance. Given that in 2012, Jember district was listed as the district with the highest IMR and MMR in East Java. One of the collaborative policy programs launched to reduce the high IMR and MMR in Jember Regency is the Copy of Decision of Jember Regent Number: 188.45 / 101.1 / 012/2015 About Perinatal Maternal Audit Team of Jember Regency Year 2015. The descriptive qualitative research method used (before the C19 pandemic) was in-depth interviews, three FGDs with stakeholders. Data analysis by Spreadly analysis (taxonomic analysis, component analysis and cultural themes). The results showed that the ego-centricity of each government institution was still very prominent, and community participation was still mobilizing. Thus, efforts to strengthen collaborative governance roles are needed through the role of leading actors who are strongly committed to directing, controlling and monitoring policy programs that have been made.
\end{abstract}

\section{Keywords:}

collaborative governance; mother; infant mortality rate

\section{Introduction}

Based on data from the East Java Central Statistics Agency (BPS) in 2012, it shows that infant mortality and maternal mortality rates are still high in East Java Province. Although the average figure in East Java province has reached the target, it has even exceeded the national target in the 2014-2019 RPJMN. Based on a report prepared by the East Java Strategic Plan Health Office for 2009-2014, several main issues-related to infant mortality rates, are still faced by the province of East Java: 1) poor quality of land surface and groundwater pollution, global warming, environmental damage and poorly organized household waste disposal systems, causing reduced access to clean water to the community, especially the poor, 2) unequal distribution of health personnel, they are more concentrated in urban areas. 3) Low accessibility for quality health services, especially in poor, underdeveloped, remote, 
marginalized areas and islands (Consolidated Accountability Report for the Governor of East Java Province Chapter IV - 1135 in 2011).

Related to efforts to reduce maternal and infant mortality, especially in East Java, the policies that regulate this, namely Law number 36 of 2009 concerning Health articles 126 and 131, namely, the government regulates the right to health services and protection for mothers and children. In the design, the implementation of these rights is directed through strategic policies and activities to reduce MMR and IMR. In addition, other policies related to maternal and infant health are the East Java Regional Regulation Number 3 of 2014 concerning RPJMN 2014-2019 Chapter 8 and the targets in Article 9.

However, if you pay attention, the distribution of maternal and infant mortality cases in East Java is unique because the high IMR and MMR are in the horseshoe area of East Java.

Table 1.

Status AKB dan AKI di kabupaten daerah tapal kuda Jawa Timur pada tahun 2012

\begin{tabular}{llrrr}
\hline No & \multicolumn{1}{c}{ Kabupaten/Kota } & AHH & AKB & AKI \\
\hline & Jawa Timur & 70,09 & 28,31 & 97,43 \\
1 & Kab. Jember & 63,22 & 56,33 & 116,44 \\
2 & Kab. Bondowoso & 63,79 & 53,93 & 109,50 \\
3 & Kab. Situbondo & 63,55 & 54,94 & 142,87 \\
4 & Kab. Probolinggo & 61,52 & 63,51 & 81,07 \\
5 & Kab. Pasuruan & 64,47 & 51,07 & 111,68 \\
6 & Kab. Bangkalan & 63,64 & 54,56 & 32,60 \\
7 & Kab. Sampang & 63,66 & 54,48 & 56,45 \\
8 & Kab. Pamekasan & 64,56 & 50,69 & 84,92 \\
\hline
\end{tabular}

Source: East Java BPS, 2012 processed by researchers

Every policy has a value that is its goal. Often government policies require the role of other parties to work together in achieving these policy goals. This is often referred to as Collaborative Governance. Similarly, policies to reduce MMR and IMR in Jember district. Considering that the MMR and MMR in Jember Regency at that time were still higher than the average figure for the province of East Java.

Collaborative Governance is based on the goal of solving common problems or specific issues. The related parties are not only limited to government and non-government agencies, but involve civil society in the formulation and decision-making. Emerson and Nabatchi (2015: 17) argue that collaborative governance does not emphasize the government as the initiator. Furthermore, collaborative governance according to Emerson, Nabatchi, and Balogh 
(2012: 3) can be interpreted as a process and structure of making and implementing public policies that involve parties in government agencies and / or the private sector, and civil society to manage interests or community needs so that policy objectives can be achieved. Collaborative Governance also allows the involvement or participation of civil society in government.

Returning to the concept of Collaborative Governance, GC can be defined as stated by Jung in Kurniasih (2017) that collaborative governance is a process of forming, driving, facilitating, operationalizing and monitoring cross-sectoral organizational arrangements in solving public policy problems that cannot be resolved with just one organization. public itself.

In this case, researchers are more focused on choosing Jember district, because as a plural city and the people are relatively educated, but still have high IMR and MMR scores above the average of East Java province. Jember Regency is considered to represent several districts, including areas with high maternal and infant mortality rates. From this raises the question, how is the implementation of Health policies in an effort to reduce MMR and IMR in Jember, which are still high? What is the role of local governments in efforts to reduce MMR and IMR in Jember Regency?

\section{Method}

The research method chosen in this research is descriptive qualitative. Data were collected through direct and in-depth interviews (before the C-19 pandemic) and 3 FGDs were conducted with the local government (in this case the Health Office, BKKBN, Puskesmas, village heads and communities). In qualitative research, data analysis has been carried out since the beginning of the study and during the research being conducted. Starting from interviews, observation, classification, reduction, presentation and then drawing conclusions. The data analysis of this research uses the Spradley analysis model which includes domain analysis, taxonomy, components and analysis of cultural themes.

\section{Results and Discussion}

To overcome the problem of high IMR and MMR, the regional government of Jember district launched the GERAK BERLIAN program (Jember Concurrent Movement Cares for 
Mothers, Babies and Children) on April 8, 2015. This program is expected to be able to answer the problem of high IMR and MMR by strengthening Collaborative Governance in policy implementation

Gerak Berlian is acronym from Gerakan Serentak Jember Peduli Ibu, Bayi dan Anak in Jember Regency that cares for Mothers, Infants and Children. This movement is aimed for all pregnant mothers, laboring mothers, infants and children in Jember Regency. The goal of this movement is joint actions from all level, whether from government and all sectors (Health Department, $B P 2 K B$, Education Department, Ministry of Religious Affair, PKK, Bappekab, Village's Chiefs etc) and society. This movement aims to decrease IMR and MMR in Jember Regency. Acceleration movement in reducing IMR and MMR has been started since 2014. Thus, this Gerak Berlian was born and started to be used on 8 April 2015. Here are some goals of Gerak Berlian such as:

a. Decrease IMR from 251 in 2014 to 229 in 2015. Gerak Berlian was implemented in all Districts/Puskesmas in Jember Regencys

b. Deaths shifted from direct causes (bleeding, Preeclampsia) to indirect caused (chronic diseases)

c. Late referral ( $<3$ hours handling) that occurred could decrease into 3 cases from all cases (32 cases) compared to previous year (6 cases). This means that early detection has been well implemented by society, health workers or across sectors.

GERAK BERLIAN is implemented in all district or Public Health Service because all area has equal jobs, roles and responsibilities, in which all targets are located in some areas who have risks of mother and infant deaths. Collaborative governance efforts made regarding Gerak Berlian, they are as follow.

a. Involvement of across sectors in reducing IMR and MMR.

b. Socialization and funding support in village level.

c. Villages that have IMR and MMR must carry out an External Maternal and Perinatal Death Audit (AMP) to evaluate collaborative performance in the area

d. There is collaboration between midwives and traditional midwives

e. Improving knowledge about early detection of high risk in pregnant mother and high-risk neonatal for society 
f. In making decisions must be fast for emergency cases, related to pregnant women and childbirth

Collaborative governance of health offices and across sectors in an effort to reduce IMR and MMR in Jember Regency can be seen in the table below.

\section{Table 2.}

Collaborative governance activities in reducing maternal and infant mortality rates:

\begin{tabular}{|c|c|c|c|c|}
\hline No & Main program & & Detail Activities & Stakeholder Partners \\
\hline \multirow[t]{5}{*}{1} & $\begin{array}{l}\text { Health } \\
\text { Reproduction } \\
\text { Promotion }\end{array}$ & a. & $\begin{array}{l}\text { Providing source in promoting health } \\
\text { reproduction event held by other } \\
\text { institutions. }\end{array}$ & Health Department \\
\hline & & b. & $\begin{array}{l}\text { Coordinating planning program in } \\
\text { implementing Regency's Regulation } \\
\text { Number } 17 \text { Year } 2013 \\
\text { Coordinating the execution of } \\
\text { activities regarded to the } \\
\text { implementation of Regency's } \\
\text { Regulation Number } 17 \text { Year } 2013\end{array}$ & Bappekab \\
\hline & & e. & $\begin{array}{l}\text { Facilitating health reproduction } \\
\text { promotion in local schools } \\
\text { Integrating health reproduction } \\
\text { material into syllabus }\end{array}$ & $\begin{array}{l}\text { Department of } \\
\text { Education }\end{array}$ \\
\hline & & f. & $\begin{array}{l}\text { Facilitating health reproduction } \\
\text { education in Madrasah and Islamic } \\
\text { boarding schools }\end{array}$ & $\begin{array}{l}\text { Ministry of Religious } \\
\text { Affairs } \\
\text { Religious Figures }\end{array}$ \\
\hline & & g. & $\begin{array}{l}\text { Promoting and motivating health } \\
\text { reproduction to society }\end{array}$ & $\begin{array}{l}\text { BP2KB, Bapemas, PKK } \\
\text { (regency, district, } \\
\text { village), Camat, Kades, } \\
\text { Toma, Toga }\end{array}$ \\
\hline \multirow[t]{4}{*}{2.} & $\begin{array}{l}\text { Delaying } \\
\text { Marriage Age } \\
\text { or Pregnancy }\end{array}$ & a. & $\begin{array}{l}\text { Providing source in promoting } \\
\text { delaying marriage age or pregnancy } \\
\text { held by other institutions }\end{array}$ & Health Department \\
\hline & Promotion & b. & $\begin{array}{l}\text { Collecting and merging reports of } \\
\text { institutions by implementing } \\
\text { Regency's Regulation Number } 17 \\
\text { Year } 2013\end{array}$ & Bappekab \\
\hline & & c. & $\begin{array}{l}\text { Integrating health reproduction } \\
\text { material into syllabus in local schools, } \\
\text { madrasah, and Islamic boarding } \\
\text { schools }\end{array}$ & $\begin{array}{l}\text { Dinas Pendidikan, } \\
\text { Kemenag, Toga }\end{array}$ \\
\hline & & d. & $\begin{array}{l}\text { Promoting and motivating society in } \\
\text { delaying marriage age and pregnancy }\end{array}$ & $\begin{array}{l}\text { BP2KB, Bapemmas, } \\
\text { PKK, Camat, Kades, } \\
\text { Toma, Toga }\end{array}$ \\
\hline
\end{tabular}




\begin{tabular}{|c|c|c|c|}
\hline No & Main program & Detail Activities & Stakeholder Partners \\
\hline \multirow[t]{5}{*}{3.} & $\begin{array}{l}\text { Health Facility } \\
\text { and Service } \\
\text { Improvement } \\
\text { Based on } \\
\text { Standardized } \\
\text { Procedures } \\
\text { (SOP) of Safe } \\
\text { Childbirth in } \\
\text { Health Facility }\end{array}$ & $\begin{array}{l}\text { a. Advocating and researching in } \\
\text { developing policies to support safe } \\
\text { childbirth, early breast-feeding, and } \\
\text { exclusive breastfeeding } \\
\text { b. Planning, developing and } \\
\text { disseminating SOP } \\
\text { c. Giving practical training about safe } \\
\text { childbirth, early breast-feeding, and } \\
\text { exclusive breastfeeding and } \\
\text { breastfeeding counseling to health } \\
\text { workers } \\
\text { d. Implementing safe childbirth service, } \\
\text { early breastfeeding, and exclusive } \\
\text { breastfeeding in public health service, } \\
\text { Ponkesdes, and Polindes }\end{array}$ & $\begin{array}{l}\text { Health Department, } \\
\text { PKM, RS, BP2KP }\end{array}$ \\
\hline & & $\begin{array}{l}\text { e. Nurturing private health facility to } \\
\text { implement SOP in safe childbirth, } \\
\text { early breastfeeding, exclusive } \\
\text { breastfeeding, and giving practical } \\
\text { trainings to health workers } \\
\text { f. Facilitating villages }\end{array}$ & $\begin{array}{l}\text { Dinkes, Puskesmas, } \\
\text { RS, Klinik , Camat, } \\
\text { Kades, PKK }\end{array}$ \\
\hline & & $\begin{array}{l}\text { g. Promoting safe childbirth to society, } \\
\text { especially to future brides and } \\
\text { grooms }\end{array}$ & $\begin{array}{l}\text { Dinkes, Bapemmas, } \\
\text { BP2KB, Kemenag, } \\
\text { PKM, Camat, Kades, } \\
\text { Toma, Toga, PKK, } \\
\text { Kader }\end{array}$ \\
\hline & & $\begin{array}{l}\text { h. Optimizing the implementation of } \\
\text { P4K } \\
\text { i. Facilitating society to develop } \\
\text { villages }\end{array}$ & $\begin{array}{l}\text { Dinkes, PKM, Camat, } \\
\text { Kades, PKK, Toma, } \\
\text { Toga, Kader }\end{array}$ \\
\hline & & $\begin{array}{l}\text { j. Providing contraception to husbands } \\
\text { and wives who need }\end{array}$ & ВР2КР \\
\hline \multirow[t]{2}{*}{4.} & $\begin{array}{l}\text { Early Breast- } \\
\text { Feeding }\end{array}$ & $\begin{array}{l}\text { a. Promoting early breast-feeding to } \\
\text { society, especially to future brides } \\
\text { and grooms }\end{array}$ & $\begin{array}{l}\text { Kemenag, BP2KB, } \\
\text { Toma, Toga, Camat, } \\
\text { Kades, PKK, Kader }\end{array}$ \\
\hline & & $\begin{array}{l}\text { b. Giving practical trainings related to } \\
\text { early breast-feeding to health workers }\end{array}$ & $\begin{array}{l}\text { Hospitals, } \\
\text { BP2KP }\end{array}$ \\
\hline 5. & $\begin{array}{l}\text { Giving } \\
\text { Exclusive } \\
\text { Breast-Feeding }\end{array}$ & $\begin{array}{l}\text { a. Promoting to school students about } \\
\text { women's rights to breastfeed their } \\
\text { babies exclusively }\end{array}$ & $\begin{array}{l}\text { Education } \\
\text { Department, Health } \\
\text { Department, } \\
\text { Puskesmas, Hospital, } \\
\text { Ministry of Religious }\end{array}$ \\
\hline
\end{tabular}




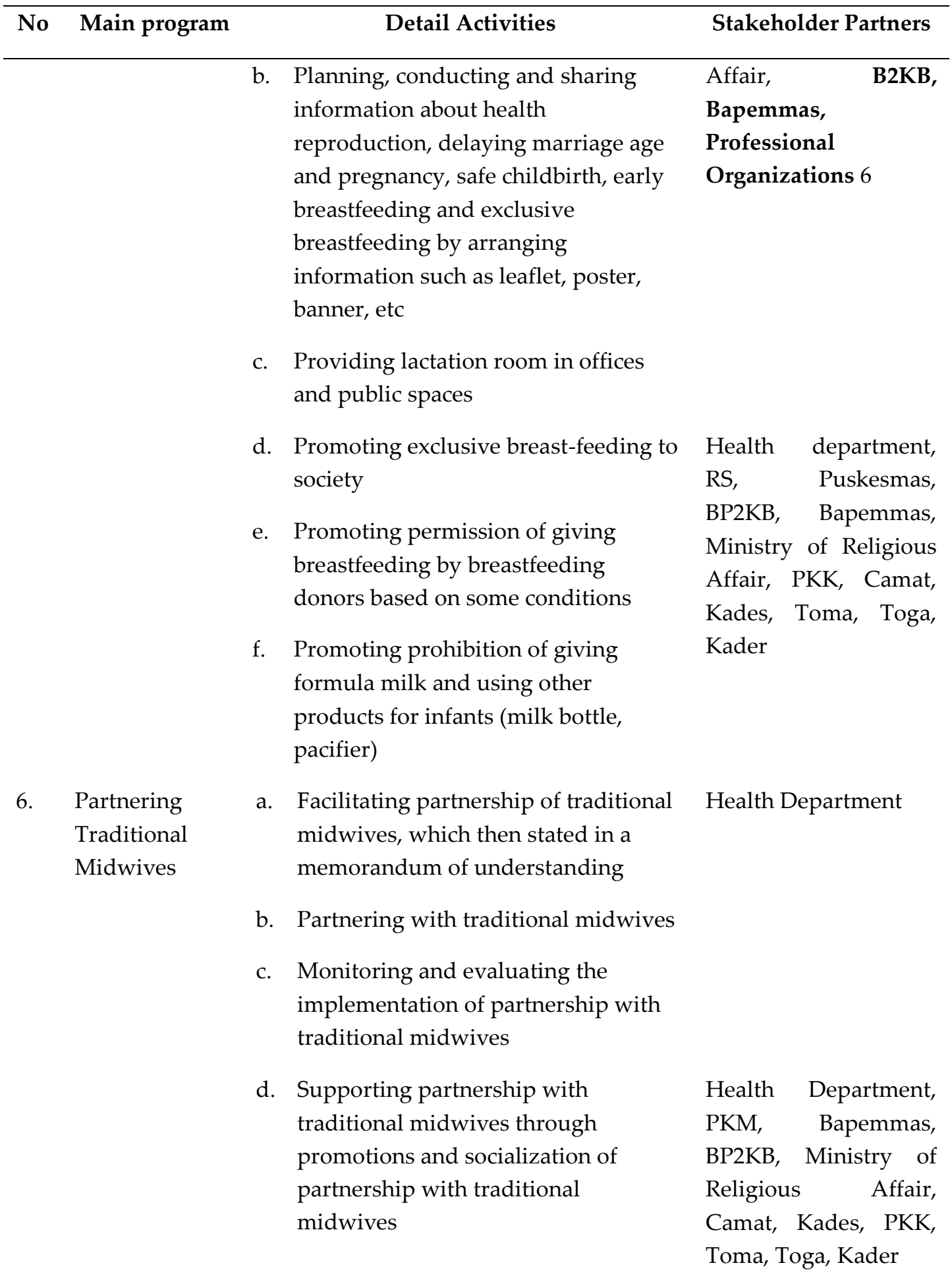

Source: Jember Health Department, 2016, processed by researchers

The table above shows stakeholder involvement through collaborative governance with each program that was broken down from the policy to reduce IMR and MMR in Jember district. 


\section{Conclusion}

In implementing the policy to reduce MMR and IMR, cooperation and the role of other parties or institutions are needed. It's just that there are still obstacles related to the egocentricity of each institution involved in implementing policies within the framework of collaborative governance. The role of government agencies in implementing the IMR and MMR reduction policies is still dominant, because community participation is still low and requires mobilization from leaders in their regions. The role of a leader who is strongly committed to regulating, controlling and monitoring the performance of institutions involved in collaborative governance is still very much needed, in order to achieve the achievement of policy objectives for the welfare of the community.

\section{References}

$\begin{array}{llll}\text { Departemen } & \text { Kesehatan } & \text { RI, } & \text { 2003, }\end{array}$

https://www.kemkes.go.id/resources/download/pusdatin/profil-kesehatanindonesia/profil-kesehatan-indonesia-2004.pdf. Accessed on Juni 2012,

Emerson, Kirk dan Tina Nabatchi. 2015. Collaborative Governance Regime. Washington: Georgetown University.

Emerson, Kirk, Tina Nabatchi, and Stephen Balogh. 2012. An Integrative Framework for Collaborative Governance." Journal of Public Administration Research and Theory. Vol 22 No 1

Kurniasih, D. et al. 2017. Collaborative Governance Dalam Penguatan Kelembagaan Program Sanitasi Lingkungan Berbasis Masyarakat (Slbm) Di Kabupaten Banyumas. Sosiohumaniora, Vol 19 No. 1: $1-7$

Laporan Keterangan Pertanggung Jawaban Gubernur Tahun 2011 Provinsi Jawa Timur (BAB IV 1135) from http://bappeda.jatimprov.go.id/laporan/

RPJMD Propinsi Jawa Timur 2014-2019, from http://bappeda.jatimprov.go.id/2016/11/09/rpjmd-jatim-2014-2019-fokuspembangunan-seni-dan-budaya/ 


\title{
Collaborative Governance: Revitalization of Citrus Village Tourism in Malang in the New Normal Era
}

\author{
Erna Setijaningrum \\ Departemen Administrasi, Fakultas Ilmu Sosial dan Ilmu Politik, Universitas Airlangga \\ (email: erna.setijaningrum@fisip.unair.ac.id)
}

\begin{abstract}
Citrus Village tourism, located in Selorejo Village, Dau District, Malang Regency, is one of the tourist destinations affected by the Covid-19 pandemic. As a result of the Large-Scale Social Restrictions policy which was followed by the closure of all tourist objects which resulted in a drastic reduction in tourist visits and even none at all. As a result, this tourism turnover was originally around 5 billion per year, to just 500 million. Along with the implementation of the new normal, these tours are slowly starting to be visited by tourists. To revive this tourism, the Selorejo Village Government is collaborating with several parties. Therefore, this research is based on how collaborative governance is implemented. This research uses a descriptive qualitative approach. To answer the problem formulation, a collaborative governance theory model from Morse \& Stephens (2012) is used. The results showed that the collaboration process begins with assessment, initiation, deliberation, and implementation. The conclusion is that the dominant factor in this collaboration process is the strong commitment of all actors to revitalize Citrus Village tourism in the new era of normalcy so that it becomes a favorite destination. In addition, the spirit to become a 'Independent Village' with Citrus Village tours as an economic support also strengthens collaboration between actors.
\end{abstract}

\section{Keywords:}

collaborative governance; Citrus Village tourism; new normal

\section{Introduction}

The impact of the Covid-19 pandemic has hit the world of tourism, including tourism in Citrus Village, which is located in Selorejo Village, Dau District, Malang Regency. Nature tourism with a land area of 25 ha was originally able to generate a turnover of up to 5 billion each year, but during the Covid-19 pandemic it could only reach 500 million.

As a result of the Large-Scale Social Restrictions policy which was followed by the closure of all tourist objects, visitors drastically reduced even no visitors. As a result, all aspects related to tourism have decreased incomes. Starting from parking attendants, who all can get income from parking fees of around 200 vehicles per week, now there are no more. 
Food vendors in the "Bedengan" - protected forest - adjacent to the citrus plantation also went bankrupt. A total of 17 stalls had to be closed during the COVID-19 pandemic. The tour agents who were originally able to bring in groups of around 10 tourists each week are no longer there. Even the tour guides also lost their jobs because no guests were welcomed.

But now, slowly everything is starting to recover. With the implementation of the new normal, the Citrus Village tourism is reopened to the public. Slowly, turnover began to rise again with the opening of this tourist spot in the new normal era. To revive this tourism, the Selorejo Village Government is collaborating with several parties. Therefore, this study intends to see how collaborative governance is implemented.

\section{Methods}

This research uses a qualitative descriptive method which tends to be based on the textual context used to gain an understanding of the reasons and motivations that underlie social phenomena (Neuman, 2016). Qualitative research is an approach to exploring and understanding the meaning of an individual or group as a social or human problem (Creswell, 2017). Data collection techniques through three ways, namely observation, interviews, and documentation. Data analysis includes three steps from (Miles, et al, 2014), namely data collection, data condensation, data display, conclusion and drawing / verifying.

The research location is in Selorejo Village, Dau District, Malang Regency. The research period was about 3 months from August - October 2020. The selection of informants was carried out using purposive sampling and snowball techniques (Cresweel, 2017), starting with an initial interview with the Village Government officials (Head of the Community Welfare section), then flowing to the chairman of the Tourism Awareness Group, farmers, collectors, tour guides, and tour agents.

\section{Results and Discussion}

\section{Citrus Village Tourism Profile}

Citrus village tourism is the newest tourist attraction in Selorejo Village, Dau District, Malang Regency. This tour was inaugurated since last April 2016. As a new tourist attraction in Malang Regency, Citrus Village offers an innovation that is different from other tourist destinations. At this location, tourists can eat as much as they like in the citrus garden. 
Tourists can also pick as many citrus as they like, then take them home. Citrus Village tours are open from 08.00-17.00 every day. To enter this tourist location, you have to pay 15 thousand rupiah for adults and 8000 rupiah for children. In order to increase the comfort of visitors, a hat is provided as a protection from the hot sun. There are also mats for sitting around enjoying the citrus that have been picked in the garden. Along the street there are citrus stalls selling a variety of fresh citrus at low prices.

Figure 1.

\section{Gate of Citrus Village Tourism}

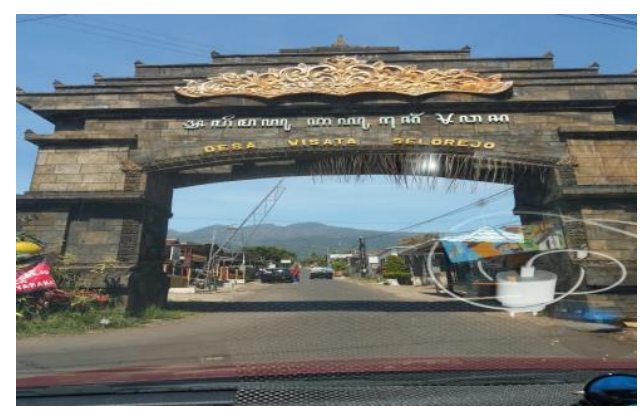

Figure 3.

Citrus Garden

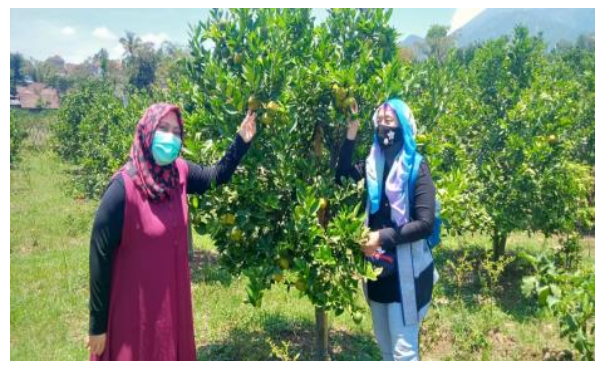

Figure 2.

The village hall located in the citrus

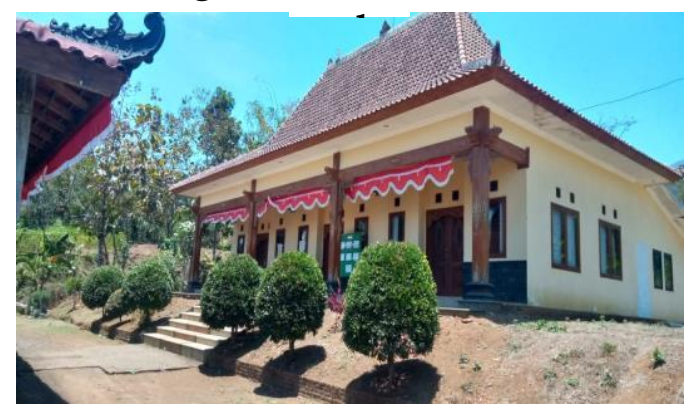

Figure 4.

Citrus Tree

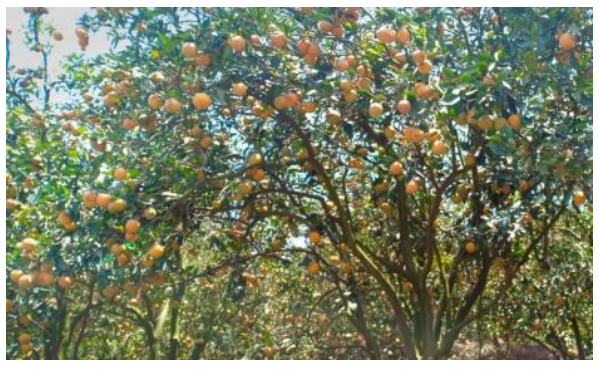

This Citrus Village Tour has an area of 25 ha. This land belongs to the village administration, which is leased to farmers for an area of 18 ha. Meanwhile, an area of 7 ha is managed by the village itself. The farmer are around 1000 people. Next to the citrus plantation, there is a protection forest called "Bedengan". There is a place for culinary tourists, namely "Soto Bedengan".

Figure 5.

Citrus garden wich is managed by village government

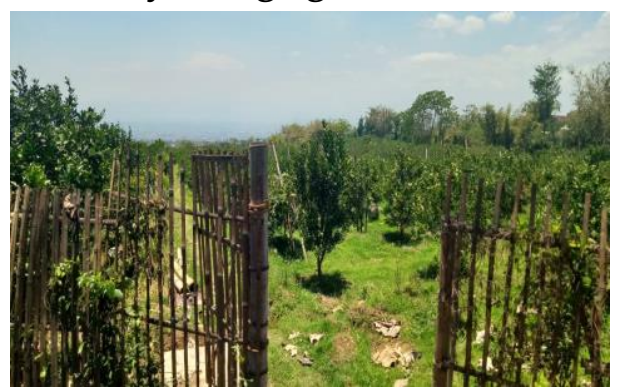

Figure 6. Citrus garden wich is managed by farmers

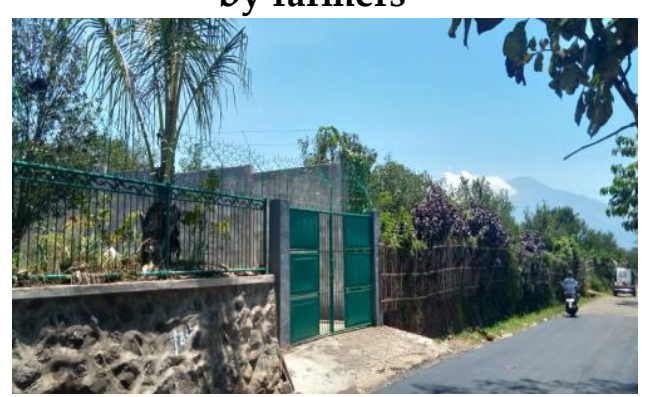


Figure 7.

Citrus vending stall

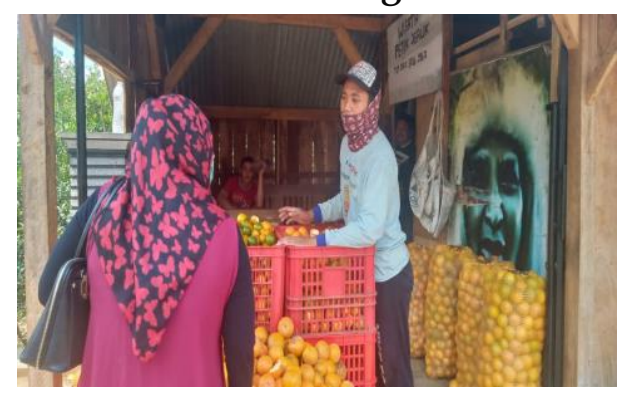

Figure 8.

Soto Bedengan

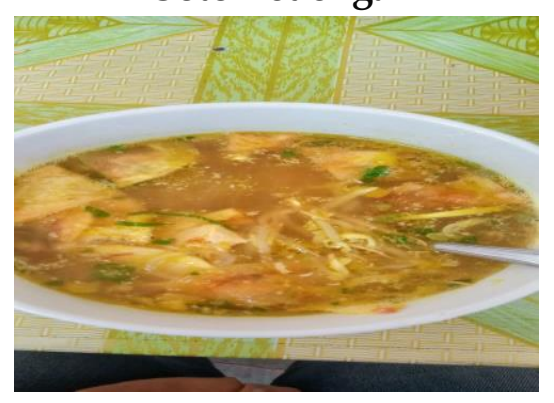

\section{Collaborative Governance}

According to Tiihonen (2004) governance is a new process of governance or a new method of governance. The government is not only the government, but actors from various sectors who are involved in the government process. Governance is characterized by the participation of other actors in decision making. As a result, in terms of public service and decision making there is collaboration between actors. Actors involved in the governance process are government, private sector, and society. The government is no longer the sole actor and monopolizes all government administration, but these three actors are influential in the governance process. Ansell and Gash (2007) describe collaborative governance as a model that involves various kinds of stakeholders in decision making. Rosemary et al (2009) define collaborative governance as a multi-organizational arrangement in the process of running and facilitating something which cannot be resolved by one organization alone. Emerson \& Tina (2015) describes collaborative governance as a process that aims to carry out public goals that involve communities outside government actors, public agencies at every level of government, and the private sector in which there are public management processes and public decision making.

\section{Collaborative governance model}

The collaborative governance model according to Morse and Stephens (2012) in their article entitled Teaching Collaborative Governance: Phases, Competencies, and Case-Based 
Learning has four stages in the process, namely assessment, initiation, deliberation, and implementation as follows:

Tabel 1.

Model Collaborative Governance

\begin{tabular}{|c|c|c|c|}
\hline Assessment & Initiation & Deliberation & Implementation \\
\hline $\begin{array}{l}\text { Is collaboration } \\
\text { necessary? }\end{array}$ & $\begin{array}{l}\text { How to frame the } \\
\text { issue? }\end{array}$ & How to develop & Who will do \\
\hline $\begin{array}{l}\text { Are precondition } \\
\text { in place? }\end{array}$ & $\begin{array}{l}\text { How to engage } \\
\text { stakeholders? }\end{array}$ & $\begin{array}{l}\text { group } \\
\text { What ground rules }\end{array}$ & $\begin{array}{l}\text { How to broaden } \\
\text { support? }\end{array}$ \\
\hline $\begin{array}{l}\text { Who are the } \\
\text { stakeholders? }\end{array}$ & $\begin{array}{l}\text { Who/what else is } \\
\text { needed? }\end{array}$ & $\begin{array}{l}\text { ? } \\
\text { How to invent }\end{array}$ & $\begin{array}{l}\text { What kind of } \\
\text { governance }\end{array}$ \\
\hline Who might fill key & What & options and decide & structure? \\
\hline roles? & process? & $\begin{array}{l}\text { ? } \\
\text { How to facilitate } \\
\text { mutual learning? }\end{array}$ & $\begin{array}{l}\text { How to mkonitor } \\
\text { progress? }\end{array}$ \\
\hline
\end{tabular}

Source : Morse \& Stephens (2012)

The next presentation explains the four stages in collaborative governance on Citrus Village tours. First, the assessment that has been carried out by the Selorejo Village Government determines that to optimize Citrus Village tourism requires collaboration with several parties. With the assumption that the Village Government cannot run alone due to limited funds, manpower, human resources, and expertise, other actors are needed to work together. The prerequisite for collaboration is mutually beneficial for both parties. The stakeholders involved are the Selorejo Village Government representing the government; BRI, tour agents, and collectors represent the private sector; farmers and tour guides represent society. Meanwhile, the key actor in this collaboration is the Selorejo Village Government who will accommodate everything. The following table describes the assessments in this collaboration.

Tabel 2.

Assessment in collaborative governance

\begin{tabular}{cl}
\hline \multicolumn{1}{c}{ Assessment } & \multicolumn{1}{c}{ Explanation } \\
\hline Is collaboration necessary? & $\begin{array}{l}\text { Collaboration is very important because the } \\
\text { village government is unable to run it alone, so it } \\
\text { needs other actors. }\end{array}$ \\
Are precondition in place? & $\begin{array}{l}\text { Collaboration requirements are for the common } \\
\text { good. }\end{array}$ \\
Who are the stakeholders? & $\begin{array}{l}\text { The stakeholders involved are the Selorejo Village } \\
\text { Government represent the government; BRI, tour }\end{array}$ \\
\hline
\end{tabular}




\begin{tabular}{|c|c|}
\hline & $\begin{array}{l}\text { agents, and collectors represent the private sector; } \\
\text { farmers and tour guides represent society }\end{array}$ \\
\hline Who might fill key roles? & $\begin{array}{l}\text { The key role in collaboration is the village } \\
\text { government }\end{array}$ \\
\hline
\end{tabular}

Source: Data processing

This study found that it is related to "Who might fill key roles?" In the orange picking tourism collaboration, it is clear that the key role is the village government. With its authority, the village government can have the power to lead the implementation of collaboration. The leadership element plays an important role in the collaboration process. This is also shown by Bichler et al. (2019) that leadership is an important driving factor in collaborative governance in tourism management.

Second, the initiation stage, the village government seeks to immediately reduce the turnover experienced by Citrus Village tourism. By inviting collaborations with several predetermined parties, it is hoped that it can immediately make Citrus Village tourism a favorite destination for the community again. The principle of collaboration that is emphasized is mutually beneficial cooperation with the initiation of an official agreement between the BRI bank and the village government regarding the CSR of Kampung BRI, with smallholders, collectors, and tour agents. In the future, a tour package design that can attract tourists is still needed. Tourists who come not only enjoy picking citrus, but there are other aspects that can be obtained, for example local specialties.

Table 3.

Initiation in collaborative governance

\begin{tabular}{ll}
\hline \multicolumn{1}{c}{ Assessment } & \multicolumn{1}{c}{ Explanation } \\
\hline How to frame the issue? & $\begin{array}{l}\text { The impact of Covid-19 has caused Citrus Village } \\
\text { tourism to experience a decline in turnover } \\
\text { How to engage } \\
\text { stakeholders? }\end{array}$ \\
Who/what else is needed ? & $\begin{array}{l}\text { Attractive tour package design. } \\
\text { principle of mutual benefit. }\end{array}$ \\
What kind of process? & $\begin{array}{l}\text { The collaboration started with BRI through BRI's } \\
\text { CSR, namely BRI Village. Furthermore, involving } \\
\text { farmers and other stakeholders to support. }\end{array}$ \\
\hline
\end{tabular}

Source: Data processing

An overview of "How to engage stakeholders?" in Citrus Village tourism governance collaboration, each stakeholder will benefit from this collaboration. Therefore, all stakeholders work together to promote Citrus Village tours in order to attract tourists. This 
is the same as research from Utami, et al (2019) which describes how stakeholders are involved in collaborating to promote tourism in the Sumenep Palace to attract visitors.

Third, deliberation was carried out with each actor playing a role according to the needs of developing Citrus Village tours. The village government makes rules in the form of a cooperation agreement. Apart from that, the village government also provides a place to discuss and invite stakeholders.

Table 4.

Deliberation dalam collaborative governance

\begin{tabular}{|c|c|}
\hline Assessment & Explanation \\
\hline $\begin{array}{l}\text { How to develop effective } \\
\text { working group? }\end{array}$ & $\begin{array}{l}\text { All stakeholders are interrelated and dependent. } \\
\text { BRI plays a role in providing financial credit } \\
\text { assistance and providing training. Farmers get } \\
\text { credit and training. Farmers also have an } \\
\text { important war because they are cultivating } \\
\text { farmers. Tour agents market tours, Tour guides } \\
\text { welcome tourists who come. Collectors distribute } \\
\text { their crops. }\end{array}$ \\
\hline What ground rules? & $\begin{array}{l}\text { The basic rules are based on a cooperation } \\
\text { agreement }\end{array}$ \\
\hline $\begin{array}{l}\text { How to invent options } \\
\text { and decide? }\end{array}$ & Discussions were held \\
\hline $\begin{array}{l}\text { How to facilitate mutual } \\
\text { learning? }\end{array}$ & $\begin{array}{l}\text { The village government provides a place to } \\
\text { discuss and invite stakeholders }\end{array}$ \\
\hline
\end{tabular}

Source: Data processing

This study found that the item "How to develop an effective working group?" In this Citrus Village tourism collaboration, the community to become cultivators has an important role. His position as a cultivator is a major role in Citrus Village tours. The importance of the community's role in a collaboration related to tourism was also shown by Djosetro et al. (2020) that local communities play a very important role in collaboration, especially in strengthening decision making. Meanwhile, "How to invent options and decide?" done by discussion together. The Selorejo village government invites all stakeholders related to collaboration to make joint decisions. In contrast to the results of research conducted by Wiwin et al (2020), it shows that the cooperative relationship is still very strongly controlled by the government. The private sector and society are not involved in decision making so that the services provided to tourists are still not optimal.

Fourth, the implementation stage is carried out by the Village Government by providing protection and legal certainty in the collaborative process; BRI as a private party uses CSR funds to provide training to farmers and mothers, making village applications for 
socialization and tourism promotion, and capital loans; and the community with their ability to act as smallholders. While the tour agent is the party that brings in tourists, collectors as the distributor of the citrus harvest, and the tour guide as a guest introduction to support all activities in the field.

Table 5.

Implementation in collaborative governance

\begin{tabular}{|c|c|}
\hline Assessment & Explanation \\
\hline Who will do what? & $\begin{array}{l}\text { The village government provides legal certainty } \\
\text { regarding cooperation } \\
\text { BRI provides CSR training for farmers and mothers, } \\
\text { developing village applications for socialization } \\
\text { and tourism promotion, as well as capital loans; } \\
\text { Tour agents carry out promotions and bring } \\
\text { tourists to visit } \\
\text { Collectors buy citrus crops } \\
\text { Farmers who cultivate citrus orchards } \\
\text { Tour guides welcome tours that come }\end{array}$ \\
\hline How to broaden support? & $\begin{array}{l}\text { The spirit to become an independent village } \\
\text { through citrus picking tours as a support for } \\
\text { village finances. }\end{array}$ \\
\hline $\begin{array}{l}\text { What kind of governance } \\
\text { structure? }\end{array}$ & $\begin{array}{l}\text { The governance structure is the village } \\
\text { government as a protector by providing legal } \\
\text { certainty, the main stakeholders are farmers, the } \\
\text { supporting stakeholders are BRI, tour agents, } \\
\text { collectors, and tour guides. }\end{array}$ \\
\hline How to monitor progress? & $\begin{array}{l}\text { The village government monitors the progress of } \\
\text { the collaboration }\end{array}$ \\
\hline
\end{tabular}

Source: Data processing

Describing the question "Who will do what?", the collaborative governance implemented by the Selorejo village government provides opportunities for the community, represented by farmers, to work on citrus plantation land. This is the same as research conducted by Kwiatkowski, et al (2019) which also describes community involvement in the optimization of beach tourism. The community acts as a volunteer who cleans and maintains beach facilities.

\section{Conclusion}

What seems dominant in this collaboration process is the strong commitment of all actors to return the Citrus Village tourism to the way it was before the Covid 19 pandemic. In addition, the enthusiasm to become an 'Independent Village' with Citrus Village tours as an economic support also strengthens collaboration between actors. 


\section{Reference}

Ansell, Chris dan Gash, Alison. 2007. Collaborative governance in Theory and Practice. Journal of Public Administration Research and Theory. Vol. 18, 543-571 DOI: 10.1093/jopart/mum032

Bichler, Bernhard Fabian. Lösch, Magdalena . 2019. Collaborative Governance in Tourism: Empirical Insights into a Community-Oriented Destination. Journal of Sustainability (Special Issue : Stakeholder Management in Tourism Destinations). Vol 11 - issue 23. https://doi.org/10.3390/su11236673. Pages 1-19

Creswell. J. W. (2017) Research Design : Qualitative, Quantitative and Mixed Method Approach. SAGE Publications, Inc

Djosetro, Marijem. Behagel, Jelle Hendrik . 2020. Building local support for a coastal protected area: Collaborative governance in the Bigi Pan Multiple Use Management Area of Suriname. Journal of Marine Policy. Vol 112. https://doi.org/10.1016/j.marpol.2019.103746

Emerson, Krik \& Tina Nabatchi. 2015. Evaluating the Productivity of Collaborative Governance Regimes: A Performance Matrix. Public Performance \& Management Review, 38:4, 717747

Kwiatkowski, Grzegorz. Hjalager, Anne Mette. Liburd, Janne. Simonsen, Peter Saabye. 2019. Volunteering and collaborative governance innovation in the Wadden Sea National Park. $\begin{array}{lllllll}\text { Journal of Current Issues in Tourism. Vol } 23 & \text { - Issue } & 8 .\end{array}$ https://doi.org/10.1080/13683500.2019.1571022. Pages 971-989.

Miles, M. B., Huberman, A. M., \& Saldaña, J. (2014). Qualitative Data Analysis: A Methods Sourcebook. Retrieved from http://researchtalk.com/wp-content/uploads/2014/01/MilesHuberman-Saldana-Drawing-and-Verifying-Conclusions.pdf

Morse, Ricardo Stuart. Stephenss, Jhon. 2012. Teaching Collaborative Governance: Phases, Competencies, and Case-Based Learning. Journal of Public Affairs Education. Vol 18 -issue 3: Pages 565-583

Neuman, L. W. (2016). Social Research Methods: Qualitative and Quantitative Approach (Seventh Edition). England: Pearson Education Limited

Tiihonen, Seppo. 2004. From Governing to Governance: a Process of Change. Tamfere: Tamfere University Press. 
Utami, Istayu Pratistaning. Hadi, Khrisno. Syafrieyana,Yana. 2019. Regional Government Strategies In The Development Of Sumenep Keraton Tourism In The Perspective Collaborative Governance. Journal of Local Government Issues. Vol 2 - No 1. DOI: https://doi.org/10.22219/logos. Pages 51-74

Wiwin, I Wayan. Ardika, I Wayan. Putra, I Nyoman Darma. 2020. Collaborative Governance: As a Conceptual Model of Destination Management in the Besakih Temple Area, Karangasem Regency, Bali Province. Journal of Tourism and Hospitality Management June. Vol. 8 No. 1. ISSN: 2372-5125 (Print), 2372-5133 (Online). DOI: 10.15640/jthm.v8n1a8. Pages 76-81. 